\title{
Construction and standardization of a bioreactor for the production of alkaline protease from Bacillus licheniformis (NCIM-2044)
}

\author{
Vamsi K.K. ${ }^{1}$, Boraste A. ${ }^{2}$, Jhadav A. ${ }^{3}$, Khairnar Y. ${ }^{3}$, Gupta $N^{5}{ }^{5}$, Trivedi S. ${ }^{4}$, Patil P. ${ }^{6}$, \\ Gupta G. ${ }^{7}$, Gupta M. ${ }^{5}$, Mujapara A.K. ${ }^{8}$, Joshi B. ${ }^{9}$ \\ ${ }^{1}$ Rai foundations College CBD Belapur, Navi Mumbai \\ ${ }^{2}$ S.V.P.M. College of Pharmacy, Baramati, Pune \\ ${ }^{3}$ Padmashree Dr. D.Y. Patil University, Navi Mumbai, 400614, India \\ ${ }^{4}$ V.V.P. Engineering College, Rajkot, Gujrat \\ ${ }^{5}$ Sindhu Mahavidyalaya Panchpaoli Nagpur \\ ${ }^{6}$ Dr. D. Y. Patil ACS College, Pimpri, Pune \\ ${ }^{7}$ S.D.S.M. College Palghar, Mumbai \\ ${ }^{8}$ Sir PP Institute of Science, Bhavnagar, Gujrat, adarshmujapara@gmail.com \\ ${ }^{9}$ Rural College of Pharmacy, D.S Road, Bevanahalli, Banglore
}

\begin{abstract}
Standardization of a Bioreactor for Industrial purpose is of prime importance. The construction of the Bioreactor needs a proper understanding of the different parts of the bioreactor and how they could be used. Hence the basic focus of this work was the Construction and the Standardization of the Bioreactor. The Production of Protease was done by altering the $\mathrm{pH}$ and checking the $\mathrm{KL}$ a level in the fermentation Process.
\end{abstract}

\section{Introduction}

Enzymes are biocatalysts, that catalyze (i.e. accelerate) chemical reactions [1]. In enzymatic reactions, the molecules at the beginning of the process are called substrates, and the enzyme converts them into different molecules, the products. Bacillus licheniformis is a Grampositive, spore-forming bacterium widely distributed as a saprophytic organism in the environment. $B$. licheniformis is a facultative anaerobe, which may allow it to grow in additional ecological niches. Optimal temperature for enzyme secretion is between $37^{\circ} \mathrm{C}$ to $41^{\circ} \mathrm{C}$.

\section{Component parts of a fermentation process}

Regardless of the type of fermentation an established process may be divided into six basic component parts;

- The formulation of media to be used in culturing the process organism during the development of the inoculum and in the production fermenter.

- The sterilization of the medium, fermenters and ancillary equipments.

- The production of an active, pure culture in sufficient quantity to inoculate the production vessel.

- The growth of the organism in the production fermenter under optimum conditions for product formation.

- The extraction of the product and its purification.

- The disposal of effluents produced by the process.

Bioreactor: Bioreactor (fermenter) is the heart of the fermentation process. In designing and construction of a bioreactor a number of points must be considered;

Construction Materials: In fermentations with strict aseptic requirements, generally, it is

important to select materials that can withstand repeated steam sterilization cycles. Two basic types of fermenters are used;va glass vessel with a round or flat bottom and a top flanged carrying plate. All vessels of this type have to sterilized by autoclaving. A glass cylinder with stainless steel top and bottom plates and these fermenters may be sterilized in situ, but $30 \mathrm{~cm}$ diameter is the upper size limit to safely withstand working pressures [10]. Temperature Control: Normally, in the design and construction of a fermenter there must be adequate provision for temperature control which will affect the design of the vessel body as heat will be produced by microbial activity and mechanical agitation [10].

\section{Aeration and Agitation}

The type of aeration-agitation system used in a particular fermenter depends on the characteristics of the fermentation process under construction. The structural components of the fermenter involved in aeration and agitation are:

- The agitator (impeller).

- The aeration system (sparger).

- Baffles.

Volumetric Mass-Transfer Coefficient (KLa): The oxygen demand of an industrial fermentation process is normally satisfied by aerating and agitating the fermentation broth.. Rate of oxygen transfer from air bubble to the liquid phase may be described by the equation;

$\mathrm{dCL} / \mathrm{dt}=\mathrm{KLa}\left(\mathrm{C}^{*}-\mathrm{CL}\right)$

Where,

$\mathrm{CL}$ is the concentration of dissolved oxygen in the fermentation broth

$$
\text { (Mmoles dm-3) }
$$

$\mathrm{t} \quad$ is time (hours) 
$\mathrm{dCL} / \mathrm{dt}$ is the change in oxygen concentration over a time period i.e., oxygen transfer rate (Mmoles $\mathrm{O} 2 \mathrm{dm}-3 \mathrm{~h}-1)$

$\mathrm{KL} \quad$ mass transfer coefficient (cmh-1)

a is the gas/liquid interphase area per liquid volume $(\mathrm{cm} 2 \mathrm{~cm}-3)$

$\mathrm{C}^{*} \quad$ is the saturated dissolved oxygen concentration (mmoles dm-3) [10]

Determination of KLa values: The determination of the KLa of a fermenter is essential in order to establish its aeration efficiency and to quantify the effects of operating variables on the provision of oxygen. The following are the techniques used for determination of KLa;

- Sulphite oxidation technique

- Gassing-out technique

- The Static Method of Gassing-out

- The Dynamic Method of Gassing-out

The major factors involved in scale-up are:

- Inoculum development

- Sterilization

- Environmental parameters

- Nutrient availability,

- $\mathrm{pH}$,

- Temperature,

- Dissolved oxygen concentration,

- Shear condition,

- Dissolved carbon dioxide concentration

- Foam production

All the above parameters are affected by aeration and agitation, either in terms of bulk mixing or the provision of oxygen. Points a, b, c and e are related to bulk mixing whilst $\mathrm{d}, \mathrm{e}, \mathrm{f}, \& \mathrm{~g}$ are related to air flow and oxygen transfer.

Modes of Bioreactor Operations: Bioreactors can be operated in following three ways;

- Batch bioreactors

- Continuous bioreactors

Fed-batch bioreactors

\section{Materials and Method}

Organism and growth conditions: Stock cultures of Bacillus licheniformis, (NCIM 2044) obtained from N.C.L, Pune were maintained and subcultured weekly on Nutrient Agar slants. Inoculum preparation: A loopful of culture was taken out from the Nutrient Agar slant with the help of a sterile nichrome wire loop under aseptic conditions, and was used to inoculate the Alkaline Protease Producing Broth (APPB) which had already been autoclaved before inoculation. Shake flask studies: A $1.0 \mathrm{ml}$ portion of the above inoculum was transferred to 8 different $250 \mathrm{ml}$ side-arm flasks containing $100 \mathrm{ml}$ of APPB each, with $\mathrm{pH}$ range varying from 7.5 to 11.0 respectively under complete aseptic conditions. Two type of centrifugation process were carried out in order to get the supernatant containing the extracellular enzyme;
- In first process, the samples were centrifuged at $4000 \mathrm{rpm}$ for 40 mins.

- In second process, the samples were centrifuged at $16000 \mathrm{rpm}$ for 40 mins at $4^{\circ} \mathrm{C}$.

Measurement of proteolytic activity: Proteolytic activity of the organisms, recovered from the 8 different side-arm flasks of various $\mathrm{pH}$ ranges was determined on the basis of their ability to produce a clear zone of hydrolysis on skim milk agar plates by agar ditch method. Diameter of the zone of clearance was measured in $\mathrm{mm}$.

Estimation of total extracellular soluble protein: The total extracellular soluble protein content present in the supernatant was quantitatively estimated according to the Bradford method of protein estimation [9].

- The above mentioned solutions after preparation were vortexed and mixed thoroughly.

- The samples were prepared as $40 \mu$ l sample + $760 \mu \mathrm{l}$ of distilled water $+200 \mu \mathrm{l}$ Bradford reagent (volume was made up to $5 \mathrm{ml}$ as previously mentioned).

- The spectrophotometer was set at a wavelength of $595 \mathrm{~nm}$.

- The blanks were first added into clean glass cuvettes and the instrument was auto zeroed.

- Firstly, the standard solutions were added into the cuvettes and the O.D. was recorded for all the standard solutions.

- Subsequently, the samples were added into the cuvettes and the O.D. of the same was recorded.

- A graph of concentration vs. O.D. was plotted and the values of $x$ and $y$ were calculated.

- Using the values of $x$ and $y$ the concentration $/ 200 \mu$ l was calculated.

Quantification of Alkaline Protease: Protease activity was determined spectrophotometrically by the Anson method, with a slight modification. The samples were prepared by mixing $0.1 \mathrm{ml}$ enzyme (supernatant) with $1.0 \mathrm{ml}(0.5 \%$ casein) and $1.9 \mathrm{ml} 0.1 \mathrm{M}$ Tris- $\mathrm{HCl}$ Buffer, at $37^{\circ} \mathrm{C}$ for 30 min, and then the reaction was arrested by the addition of $2.0 \mathrm{ml}$ of $5 \%$ trichloroacetic acid (TCA). This mixture was centrifuged at $3500 \mathrm{~g}$ for 20min, and the released amino acids (in supernatant) were measured as tyrosine by Folin-Lowry method. The further tests for FolinLowry were carried out as follows; Firstly, a stock solution of BSA was prepared at a concentration of $0.2 \mathrm{mg} / \mathrm{ml}$, which was used for preparing the standard dilutions for the assay. The standards and the samples were prepared according to the table listed below:

Substrate utilization: Substrate utilization was carried out in order to determine the uptake of glucose from the fermentation medium by the cells for biomass production. The yield factor $(\mathrm{Y})$ 
is the measure of the efficiency of conversion of any one substrate into biomass and it can be used to predict the substrate concentration required to produce a certain biomass concentration.

It is calculated by the equation,

$\mathrm{X}=\mathrm{Y}(\mathrm{SR}-\mathrm{s})$

Where,

$\mathrm{X} \quad$ concentration of biomass produced

$\mathrm{Y}$ yield factor (biomass

produced/substrate consumed)

SR initial substrate concentration and

$\mathrm{S}$ residual substrate concentration

The Dinitrosalicylic acid reagent method was carried out in the following way: Firstly, a stock solution of glucose was prepared at a concentration of $1 \mathrm{mg} / \mathrm{ml}$, which was used for preparing the standard dilutions for the assay. The standards and the samples were prepared according to the table listed below:

Fermentation: The fermentation process was carried out in the form of batch mode, along with continuous aeration for $24 \mathrm{hrs}$. The fermenter used was a 3-L glass borosilicate vessel with a flat bottom and a top flanged carrying plate which had three orifices namely, one for inlet, one for outlet and one for the impeller shaft.

Sterilization of the fermenter: The cleaning and sterilization of vessel and all the tubings used was primarily done with distilled water, teepol, dettol and ethyl alcohol (95\%). The vessel was further placed in hot air oven after sealing the orifice with silver foil for 30 mins at $1500 \mathrm{o}$. The vessel along with the tubings were kept in ultraviolet light for 30 mins before doing the actual set up. Preparation of fermentation medium: The medium used in the bioreactor for fermentation was normal APPB, The $\mathrm{pH}$ of the medium was adjusted to 9.5. Autoclaving: Autoclaving of the bioreactor (entire components) and the medium was done separately at $1210 \mathrm{C}$ for $30 \mathrm{mins}$

KLa Determination: The KLa of the bioreactor was determined by the dynamic gassing out technique.

- Collect $44 \mathrm{ml}$ of the fermenter broth in an airtight bottle.

- Add $2 \mathrm{ml}$ each of Manganous sulfate and Alkaline iodide-azide solutions (see appendix) in succession, right at the bottom of the bottle with separate pipettes and replace the stopper.

- Shake the bottle in the upside down direction at least six times.

- Allow the brown precipitates to settle.

- Add $2 \mathrm{ml}$ of conc. sulfuric acid and shake the stoppered bottle to dissolve the brown precipitate.

- Take $50 \mathrm{ml}$ of sample in a conical flask and titrate with Sodium thiosulphate solution
$(0.025 N)$, taken in the burette, till the colour changes to pale straw.

- Add two drops of starch indicator to the above flask, which changes the colour of the contents from pale straw to blue.

- Titrate again with Sodium thiosulphate solution till the blue colour disappears [11].

The constant burette reading without culture gives the titrant reading required for the calculation of $\mathrm{C}^{*}$ and the burette readings with culture gives the titrant reading required for the calculation of $\mathrm{CL}$, which are further required to calculate the $\mathrm{KLa}$ of the bioreactor. The dissolved oxygen concentration reflects the balance between the supply of dissolved oxygen by the fermenter and the oxygen demand of the organism.

The DO of a sample is calculated by the equation;

D.O. $($ in $\mathrm{mg} / \mathrm{l})=\left(8^{*} \times 1000 \times \mathrm{Nxn}\right) / \mathrm{V}$

Where,

$\mathrm{N} \quad$ Normality of titrant used i.e., 0.025

Sodium thiosulphate

$\mathrm{n} \quad$ Value of the titrant reading

$\mathrm{V}$ Volume of sample taken out at each

interval $(44 \mathrm{ml})[11]$

Inoculation of fermenter: The microbial inoculum was added into the inoculum flask by maintaining aseptic conditions, and this inoculum was then added through inoculum port in the bioreactor aseptically, within the LAF. Downstream Processing: An important part of the fermentation process is the product recovery step, also known as downstream processing. After fermentation is over, the raw broth is treated in a series of steps to obtain the final product. Procedures used for downstream processing could be physical, chemical or biological method. In this case, cold centrifugation procedure was applied to carry out the downstream processing:

$10 \mathrm{ml}$ of the fermenter broth was removed and collected in the centrifuge tubes

The broth was then centrifuged at $16,000 \mathrm{rpm}$ for 40 mins at $40 \mathrm{C}$. The supernatant was collected and used for the further assays. Estimation of total dry biomass: The cell mass deposited at the bottom of the centrifuge tube was washed, poured on Whatman filter paper No-I and dried in hot air oven at $700 \mathrm{C}$ for $24 \mathrm{hrs}$ and its weight was measured. The amount of total dry biomass was calculated as $\mathrm{mg} / \mathrm{ml}$.

\section{Observation and Results}

$\mathrm{pH}$ optimization: The growth curve of 8 different $250 \mathrm{ml}$ side-arm flasks containing $100 \mathrm{ml}$ of APPB each, with $\mathrm{pH}$ range varying from 7.5 to 11.0 was plotted according to the O.D. readings obtained on colorimeter at $540 \mathrm{~nm}$. Table 4 O.D. value of different $\mathrm{pH}$ range at $540 \mathrm{~nm}$ 


\section{Discussion}

Shake flask studies: $B$. licheniformis showed maximum growth at $\mathrm{pH} 8.0$ as compared its growth at other various respective $\mathrm{pH}$ range varying from $\mathrm{pH} 7.5$ to $\mathrm{pH} 11.0$. During growth studies, the maximum biomass or cell mass was obtained in between $18 \mathrm{hrs}$ to $24 \mathrm{hrs}$. The growth curve of $B$. licheniformis showed three main stages, the lag phase from 0 hrs to $4 \mathrm{hrs}$, log phase from 4 hrs to $16 \mathrm{hrs}$ and stationary phase from $16 \mathrm{hrs}$ to $24 \mathrm{hrs}$. The production of alkaline protease from $B$. licheniformis is greatly influenced by initial culture $\mathrm{pH}$. The optimum $\mathrm{pH}$ for production of alkaline protease by $B$. licheniformis was 9.5, whereas, for Bacillus subtilis and Bacillus cereus it has been shown to be $\mathrm{pH} 8.2$ and $\mathrm{pH} 9.0$ respectively $[2,8]$. In the present study, however, the most significant level of growth and production of protease was supported by $\mathrm{pH}$ ranging between 8.0 to 9.5 . The stationary phase during the growth of the organism was found to be the best at $\mathrm{pH} 9.5$ as compared to other $\mathrm{pH}$ range. The entire fermentation process was carried out at room temperature $(370 \mathrm{C})$. The total soluble extracellular protein content of the fermentation medium at each and every $\mathrm{pH}$ range was estimated using the Bradford method of protein estimation. The different $\mathrm{pH}$ ranges being assayed for total extracellular soluble protein content was found to be at $\mathrm{pH} 9.5$, and was calculated to be $12.14 \mu \mathrm{g} / \mathrm{ml}$. Maximum activity was found at $\mathrm{pH} 9.5$, below or above which the activity decreased gradually as visualized from the zone of clearance on the SMA plates and as estimated by Anson method and Folin-Lowry method. The uptake of glucose from the fermentation medium by the cells for biomass production was found to be maximum at $\mathrm{pH} 10.0$ followed by $\mathrm{pH} 7.5$. Glucose was least utilized at $\mathrm{pH} 8.5$ and 11.0, followed by $\mathrm{pH} 9.5, \mathrm{pH} 10.5, \mathrm{pH}$ 9.0 and $\mathrm{pH}$ 8.0. Bioreactor studies: From the previous shake flask studies, $\mathrm{pH} 9.5$ was selected to be the optimum $\mathrm{pH}$ range for the fermentation medium used in the bioreactor for the production of the alkaline protease. The growth curve of $B$. licheniformis at $\mathrm{pH} 9.5$ showed four main stages, the lag phase from $0 \mathrm{hrs}$ to 2 hrs, log phase from 2 hrs to $10 \mathrm{hrs}$, stationary phase from $10 \mathrm{hrs}$ to $18 \mathrm{hrs}$ and death phase from $18 \mathrm{hrs}$ to $24 \mathrm{hrs}$ and beyond. Other fermentation parameters such as temperature, aeration, and agitation were standardized and kept constant for the entire fermentation period (24 hrs). The KLa value depends upon the design and operating conditions of the fermenter and will be affected by variables such as aeration rate, agitation rate and impeller design, thus their effects were also studied. The agitation rate was maintained constantly at $120 \mathrm{rpm}$ (approximately) and the volumetric mass-transfer coefficient (KLa) of the bioreactor was estimated to be
0.0855.The total extracellular soluble protein content increased gradually as the fermentation process proceeded, and at the end of the process it was calculated to be $13.57 \mu \mathrm{g} / \mathrm{ml}$. The maximum production was found to be between 12th and 16th hour (stationary phase) of the fermentation process $(2.50 \mu \mathrm{g} / \mathrm{ml}-3.89 \mu \mathrm{g} / \mathrm{ml})$, and the total amount of alkaline protease (crude) produced at the end of the process was calculated to be $5.50 \mu \mathrm{g} / \mathrm{ml}$. The amount of total biomass produced $(\mathrm{x})$ was calculated to be 2 $\mathrm{mg} / \mathrm{ml}$. The initial substrate concentration (SR) was $10 \mathrm{mg} / \mathrm{ml}$, whereas the residual substrate concentration (s) was $5.56 \mathrm{mg} / \mathrm{ml}$. Thus, the $\mathrm{Y}$ (yield factor) at the end of the fermentation process was calculated to be 0.45 . All these findings may help in making new strategies in scale-up for the production of alkaline protease from $B$. licheniformis.

\section{References}

[1] Abu Sayem S.M., Alam M.J. and Mozammel Hoq (2006) Bangladesh J. Microbiol,

[2] Hameed A.C., Natt M.A. and Evans C.S. (1996) World J. Microbiol. Biotech., 12:289-291.

[3] Ito S., Kobayashi T., Ara K., Ozaki K., Kawai S., Hatada Y. (1998) Extremophiles, 2:185-190.

[4] Mohsen Fathi Najafi, Dileep Deobagkar, Deepti Deobagkar (2005) Electronic Journal of Biotechnology, 8, 2.

[5] Ishikawa H., Ishimi K., Sugiura M., Sowa A. and Fujiwara N. (1993) Journal of Fermentation and Bioengineering, 76 (4), 300-305.

[6] Corvas International to License Incyte Genomics LifeSeq® Gold Database Online, Press Releases 2001.

[7] Gupta R., Beg Q.K., Khan S., Chauhan B. (2002) Applied Microbiology and Biotechnology, 60:381-395.

[8] Hossain M.S., lqbal M.S. and Hoq M.M, (2004) Bangladesh J. Microbiol, 21:8689.

[9] Bradford M. (1976) Analytical Biochemistry, 72, 248-254.

[10] Stanbury P.F, Whitaker A., Hall J.S. Principles of Fermentation Technology, 2'nd edition, Pergamon press; 14, 167272.

[11] Aneja K.R. Experiments in Microbiolog, plant pathology, tissue culture and Mushroom production technology, 3'rd edition, New Age International Publishers, New Delhi, 357-358.

[12] Kannan N. Handbook of Laboratory Culture Media, Reagents, Stains and Buffer, Panima Publishing Corporation New Delhi/Bangalore, 126-127. 
Table 1 - Standard Preparation for Bradford

\begin{tabular}{|r|r|r|r|}
\hline BSA $(\mu \mathrm{g})$ & \multicolumn{1}{|l|}{ BSA $(\mu \mathrm{l})$} & $\begin{array}{l}\text { Distilled } \\
\text { water } \\
(\mu \mathrm{l})\end{array}$ & $\begin{array}{l}\text { Bradford } \\
\text { reagent } \\
(\mu \mathrm{l})\end{array}$ \\
\hline 2 & 10 & 790 & 200 \\
\hline 4 & 20 & 780 & 200 \\
\hline 6 & 30 & 770 & 200 \\
\hline 8 & 40 & 760 & 200 \\
\hline 10 & 50 & 750 & 200 \\
\hline 12 & 60 & 740 & 200 \\
\hline 1 & 70 & 730 & 200 \\
\hline 16 & 80 & 720 & 200 \\
\hline 18 & 90 & 710 & 200 \\
\hline 20 & 100 & 700 & 200 \\
\hline Blank & - & 800 & 200 \\
\hline
\end{tabular}

Table 2 - Standard Preparation for Folin-Lowry

\begin{tabular}{|l|r|r|r|r|r|r|}
\hline Tube No. & Blank & 1 & 2 & 3 & 4 & 5 \\
\hline BSA (ml) & 0 & 1 & 0.25 & 0.5 & 0.75 & 1 \\
\hline $\begin{array}{l}\text { Distilled water } \\
\text { (ml) }\end{array}$ & 4 & 3.9 & 3.75 & 3.5 & 3.25 & 3 \\
\hline
\end{tabular}

Table 3 - Standard preparation for DNSA

\begin{tabular}{|r|r|r|}
\hline $\begin{array}{l}\text { Amount } \\
\text { of stock } \\
\text { solution } \\
\text { (ml) }\end{array}$ & $\begin{array}{l}\text { Distilled } \\
\text { water } \\
(\mathrm{ml})\end{array}$ & $\begin{array}{l}\text { DNSA } \\
\text { Reagent } \\
\text { (ml) }\end{array}$ \\
\hline 0.5 & 3.5 & 1 \\
\hline 1 & 3 & 1 \\
\hline 1.5 & 2.5 & 1 \\
\hline 2 & 2 & 1 \\
\hline 2.5 & 1.5 & 1 \\
\hline Blank & 4 & 1 \\
\hline
\end{tabular}

Table 4-

\begin{tabular}{|c|c|c|c|c|c|c|c|c|}
\hline Parameter & 7.5 & 8 & 8.5 & 9 & 9.5 & 10 & 10.5 & 11 \\
\hline \multicolumn{9}{|l|}{ Time (hrs) } \\
\hline 2 & 0.02 & 0.03 & 0.03 & 0.05 & 0.08 & 0.04 & 0.01 & 0.02 \\
\hline 4 & 0.16 & 0.17 & 0.15 & 0.15 & 0.16 & 0.04 & 0.01 & 0.03 \\
\hline 6 & 0.89 & 0.9 & 0.88 & 0.85 & 0.78 & 0.05 & 0.04 & 0.05 \\
\hline 8 & 1.13 & 1.13 & 1.08 & 1.1 & 1.1 & 0.12 & 0.65 & 0.63 \\
\hline 10 & 1.29 & 1.21 & 1.26 & 1.17 & 1.25 & 0.23 & 1.11 & 1.16 \\
\hline 12 & 1.34 & 1.32 & 1.35 & 1.26 & 1.27 & 0.66 & 1.22 & 1.2 \\
\hline 14 & 1.37 & 1.43 & 1.44 & 1.26 & 1.27 & 0.79 & 1.22 & 1.21 \\
\hline 16 & 1.37 & 1.63 & 1.44 & 1.27 & 1.27 & 0.86 & 1.22 & 1.2 \\
\hline 18 & 1.39 & 1.63 & 1.44 & 1.25 & 1.26 & 0.85 & 1.16 & 1.2 \\
\hline 20 & 1.4 & 1.63 & 1.46 & 1.18 & 1.24 & 0.85 & 1.17 & 1.18 \\
\hline 22 & 1.33 & 1.63 & 1.45 & 1.14 & 1.21 & 0.87 & 1.2 & 1.09 \\
\hline 24 & 1.49 & 1.63 & 1.43 & 1.12 & 1.19 & 0.84 & 1.2 & 1.1 \\
\hline
\end{tabular}


Table 5 - Diameter of zone of clearance at respective $\mathrm{pH}$ range

\begin{tabular}{|r|r|}
\hline $\mathrm{pH}$ & $\begin{array}{l}\text { Diameter } \\
(\mathrm{mm})\end{array}$ \\
\hline 7.5 & 3 \\
\hline 8 & 3 \\
\hline 8.5 & 4 \\
\hline 9 & 4.5 \\
\hline 9.5 & 6 \\
\hline 10 & 3.5 \\
\hline 10.5 & 4 \\
\hline 11 & 3 \\
\hline
\end{tabular}

Table 6 - O.D. readings for Bradford standard at $595 \mathrm{~nm}$

\begin{tabular}{|c|c|}
\hline BSA Conc & $\begin{array}{l}\text { O.D. at } 595 \\
\mathrm{~nm}\end{array}$ \\
\hline$(2 \mu \mathrm{g} / \mu \mathrm{l})$ & \\
\hline 2 & 0.034 \\
\hline 4 & 0.042 \\
\hline 6 & 0.048 \\
\hline 8 & 0.056 \\
\hline 10 & 0.061 \\
\hline 12 & 0.072 \\
\hline 14 & 0.08 \\
\hline 16 & 0.084 \\
\hline 18 & 0.09 \\
\hline 20 & 0.098 \\
\hline
\end{tabular}

Table 7 - O.D. readings for Bradford samples of different $\mathrm{pH}$ range at $595 \mathrm{~nm}$

\begin{tabular}{|r|r|r|r|}
\hline \multicolumn{1}{|l|}{$\mathrm{pH}$} & \multicolumn{1}{l|}{ O.D. at } & \multicolumn{1}{l|}{ Conc } & \multicolumn{1}{l|}{ Conc } \\
\hline & $595 \mathrm{~nm}$ & $(\mu \mathrm{g} / 200 \mu \mathrm{l})$ & $(\mu \mathrm{g} / \mathrm{ml})$ \\
\hline 7.5 & 0.024 & -0.428 & -2.14 \\
\hline 8 & 0.031 & 0.571 & 2.85 \\
\hline 8.5 & 0.033 & 0.857 & 4.28 \\
\hline 9 & 0.037 & 1.43 & 7.15 \\
\hline 9.5 & 0.044 & 2.428 & 12.14 \\
\hline 10 & 0.015 & -1.714 & -8.57 \\
\hline 10.5 & 0.03 & 0.428 & 2.14 \\
\hline 11 & 0.02 & -1 & -5 \\
\hline
\end{tabular}

Quantification of alkaline protease: Folin-Lowry method was carried out as mentioned earlier after performing Anson method. The assay was carried out on UV-spectrophotometer at $660 \mathrm{~nm}$.

Table 8 - O.D. readings for Folin-Lowry standard at $660 \mathrm{~nm}$

\begin{tabular}{|r|r|}
\hline $\begin{array}{l}\text { BSA } \\
\text { Conc } \\
(\mu \mathrm{g} / \mathrm{ml})\end{array}$ & $\begin{array}{l}\text { O.D. at } \\
660 \mathrm{~nm}\end{array}$ \\
\hline 0.1 & 0.05 \\
\hline 0.25 & 0.12 \\
\hline 0.5 & 0.194 \\
\hline 0.75 & 0.24 \\
\hline 1 & 0.32 \\
\hline
\end{tabular}

The procedure for the $\mathrm{pH}$ samples were followed as mentioned earlier, and following readings were obtained: 
Table 9 - O.D. readings and units of Protease (crude) in $\mu \mathrm{g} / \mathrm{ml}$ of different $\mathrm{pH}$ range for Folin-Lowry at 660 $n m$

\begin{tabular}{|r|r|r|}
\hline \multicolumn{1}{|l|}{$\mathrm{pH}$} & O.D. 660 & $\begin{array}{l}\text { Protease } \\
(\mathrm{crude}) \\
(\mu \mathrm{g} / \mathrm{ml})\end{array}$ \\
\hline & $\mathrm{Nm}$ & \\
\hline 7.5 & 0.152 & 2.5 \\
\hline 8 & 0.298 & 4.71 \\
\hline 8.5 & 0.244 & 3.89 \\
\hline 9 & 0.257 & 4.09 \\
\hline 9.5 & 0.322 & 5.07 \\
\hline 10 & 0.119 & 2 \\
\hline 10.5 & 0.131 & 2.18 \\
\hline 11 & 0.143 & 2.36 \\
\hline
\end{tabular}

Substrate utilization:The DNSA method was carried out to determine the substrate utilization. The assay was carried out on colorimeter at $540 \mathrm{~nm}$.

Table 10 - O.D. readings for DNSA standard at $540 \mathrm{~nm}$

\begin{tabular}{|r|r|}
\hline $\begin{array}{l}\text { Conc (1 } \\
\mathrm{mg} / \mathrm{ml})\end{array}$ & $\begin{array}{l}\text { O.D. } \text { at } \\
540 \mathrm{~nm}\end{array}$ \\
\hline 0.5 & 0.15 \\
\hline 1 & 0.24 \\
\hline 1.5 & 0.31 \\
\hline 2 & 0.42 \\
\hline 2.5 & 0.5 \\
\hline
\end{tabular}

The DNSA method for the $\mathrm{pH}$ samples were carried out as mentioned earlier.

Table 11 - O.D. readings and glucose concentration in $\mathrm{mg} / \mathrm{ml}$ of different $\mathrm{pH}$ range for DNSA at $540 \mathrm{~nm}$

\begin{tabular}{|r|r|r|}
\hline \multicolumn{1}{|l|}{$\mathrm{pH}$} & $\begin{array}{l}\text { O.D. at } \\
540 \mathrm{~nm}\end{array}$ & $\begin{array}{l}\text { Conc } \\
(\mathrm{mg} / \mathrm{ml})\end{array}$ \\
\hline 7.5 & 0.22 & 1.18 \\
\hline 8 & 0.34 & 3.18 \\
\hline 8.5 & 0.62 & 6.36 \\
\hline 9 & 0.45 & 4.43 \\
\hline 9.5 & 0.56 & 5.6 \\
\hline 10 & 0.11 & 0.56 \\
\hline 10.5 & 0.54 & 5.45 \\
\hline 11 & 0.62 & 6.36 \\
\hline
\end{tabular}

Bioreactor studies: KLa Estimation:

The KLa of the bioreactor was determined according to dynamic gassing-out technique.The dissolved oxygen of the bioreactor was calculated according to the following formula;

DO (in $\mathrm{mg} / \mathrm{l})=\left(8^{*} \times 1000 \times \mathrm{Nxn}\right) / \mathrm{V}$ 
Table $12-C^{*}$ and $C L$ values along with $D O$ value

\begin{tabular}{|c|c|c|c|c|c|}
\hline \multirow[t]{3}{*}{$\begin{array}{l}\text { Time } \\
\text { (hrs) }\end{array}$} & $\begin{array}{l}\text { No } \\
\text { Culture }\end{array}$ & $\begin{array}{l}\text { With } \\
\text { Culture }\end{array}$ & \multicolumn{2}{|c|}{ DO Calculation } & \\
\hline & \multicolumn{2}{|c|}{ Titrant Reading (ml) } & \multicolumn{2}{|c|}{ (mmoles dm-3) } & \\
\hline & $\mathrm{C}^{*}$ & $\mathrm{CL}$ & $\mathrm{C}^{*}$ & $\mathrm{CL}$ & $\ln \left(C^{*}-C\right)$ \\
\hline 2 & 3.2 & 4 & 25 & 18.18 & 1.92 \\
\hline 4 & 3.5 & 4 & 25 & 18.18 & 1.92 \\
\hline 6 & 3.9 & 3.6 & 25 & 16.36 & 2.15 \\
\hline 8 & 4.2 & 3.2 & 25 & 14.54 & 2.35 \\
\hline 10 & 4.5 & 3.2 & 25 & 14.54 & 2.35 \\
\hline 12 & 4.9 & 3.2 & 25 & 11.81 & 2.58 \\
\hline 14 & 5.2 & 2.6 & 25 & 11.81 & 2.58 \\
\hline 16 & 5.4 & 2.6 & 25 & 11.81 & 2.58 \\
\hline 18 & 5.5 & 2.6 & 25 & 11.81 & 2.58 \\
\hline 20 & 5.5 & 2.4 & 25 & 10.9 & 2.65 \\
\hline 22 & 5.5 & 1.8 & 25 & 8.18 & 2.82 \\
\hline 24 & 5.6 & 1.4 & 25 & 6.36 & 2.92 \\
\hline
\end{tabular}

NOTE: $C^{*}=5.5$ (average titrant reading for calculating saturated DO)

Figure 9 - Graphical comparison of titrant readings of $C^{*}$ and CL values

Table 13 - O.D. readings and protein concentration in $\mu \mathrm{g} / \mathrm{ml}$ of broth harvesting samples at $595 \mathrm{~nm}$

\begin{tabular}{|r|r|r|r|}
\hline $\begin{array}{l}\text { Time } \\
(\mathrm{hrs})\end{array}$ & $\begin{array}{l}\text { O.D. at } \\
595 \mathrm{~nm}\end{array}$ & Conc $(\mu \mathrm{g} / 200 \mu \mathrm{l})$ & $\begin{array}{l}\text { Conc } \\
(\mu \mathrm{g} / \mathrm{ml})\end{array}$ \\
\hline 2 & 0.012 & -2.142 & -10.71 \\
\hline 4 & 0.016 & -1.571 & -7.85 \\
\hline 6 & 0.018 & -1.285 & -6.42 \\
\hline 8 & 0.02 & -1 & -5 \\
\hline 10 & 0.022 & -0.714 & -3.57 \\
\hline 12 & 0.024 & -0.428 & -2.14 \\
\hline 14 & 0.029 & 0.285 & 1.42 \\
\hline 16 & 0.033 & 0.857 & 4.28 \\
\hline 18 & 0.037 & 1.428 & 7.14 \\
\hline 20 & 0.04 & 1.857 & 9.3 \\
\hline 22 & 0.044 & 2.428 & 12.14 \\
\hline 24 & 0.046 & 2.714 & 13.57 \\
\hline
\end{tabular}

Table 14 - O.D. readings and glucose concentration in $\mathrm{mg} / \mathrm{ml}$ of broth harvesting samples at $540 \mathrm{~nm}$

\begin{tabular}{|r|r|r|}
\hline \multicolumn{1}{|l|}{ Time } & \multicolumn{1}{|l|}{$\begin{array}{l}\text { O.D } \text { at } \\
540 \mathrm{~nm}\end{array}$} & \multicolumn{1}{l|}{$\begin{array}{l}\text { Conc } \\
(\mathrm{mg} / \mathrm{ml})\end{array}$} \\
\hline 2 & 0.95 & 10.11 \\
\hline 4 & 0.9 & 9.54 \\
\hline 6 & 0.85 & 8.97 \\
\hline 8 & 0.78 & 8.18 \\
\hline 10 & 0.72 & 7.5 \\
\hline 12 & 0.72 & 7.5 \\
\hline 14 & 0.7 & 7.27 \\
\hline 16 & 0.65 & 6.7 \\
\hline 18 & 0.64 & 6.59 \\
\hline 20 & 0.58 & 5.9 \\
\hline 22 & 0.56 & 5.68 \\
\hline 24 & 0.55 & 5.56 \\
\hline
\end{tabular}




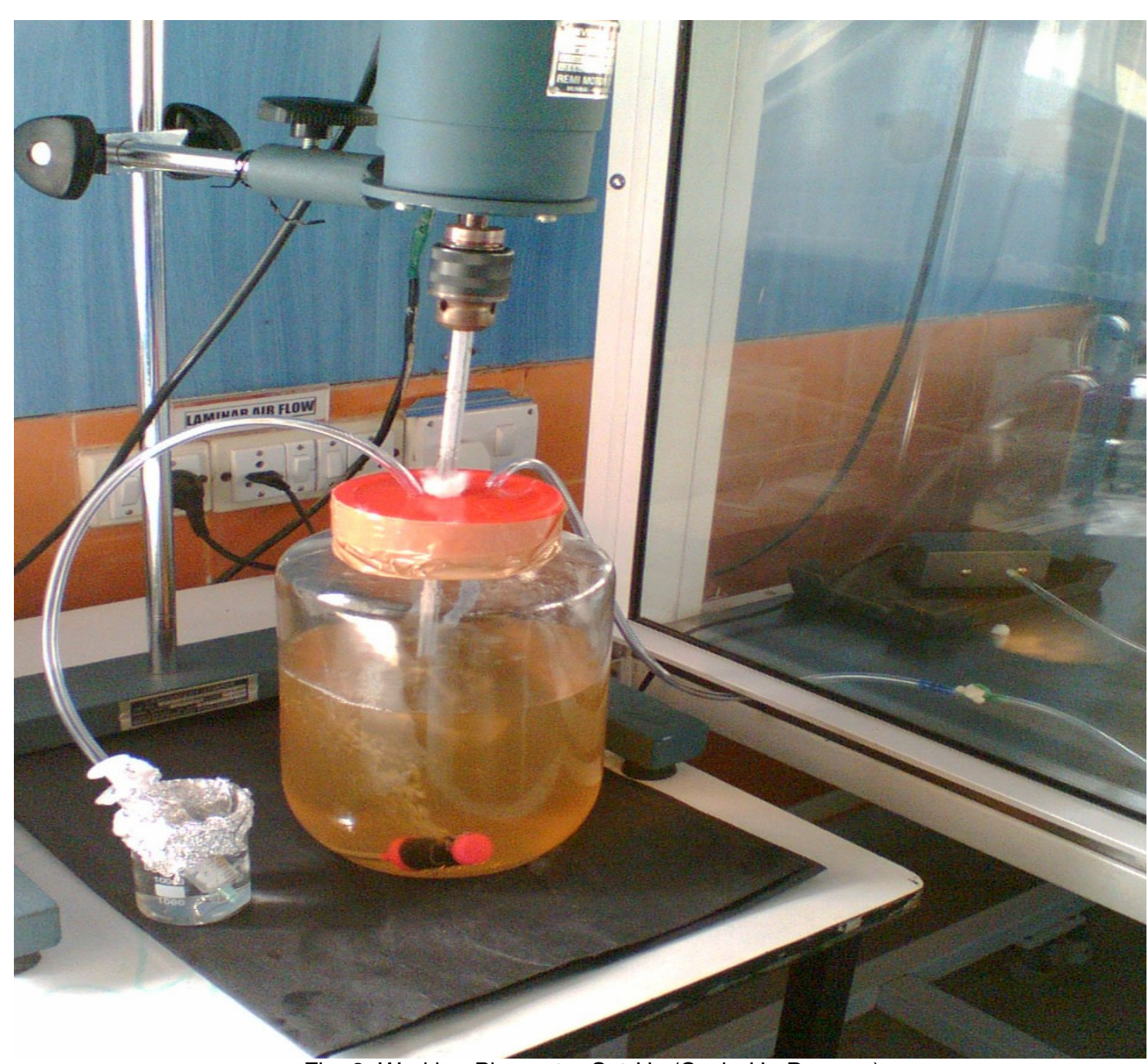

Fig. 2- Working Bioreactor Set-Up (Scale-Up Process)

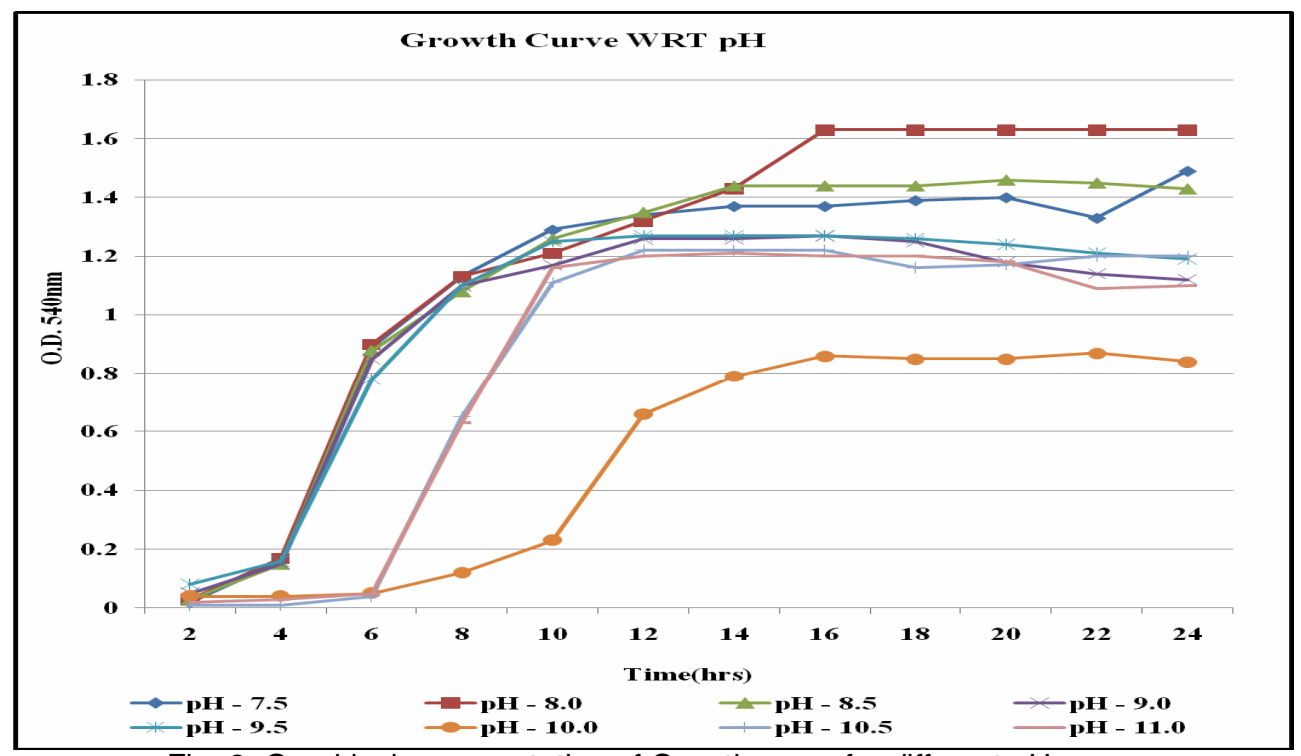

Fig. 2- Graphical representation of Growth curve for different $\mathrm{pH}$ range 
Measurement of proteolytic activity: B. licheniformis demonstrated a large zone of hydrolysis around the large colony on SMA medium.

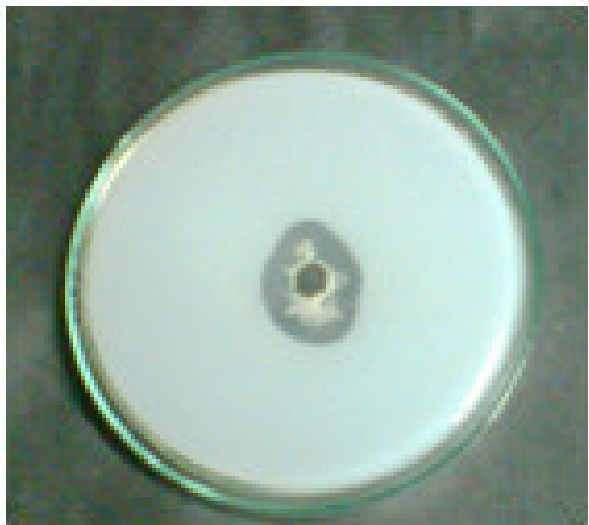

$\perp \mathrm{PH}+\mathrm{S}$

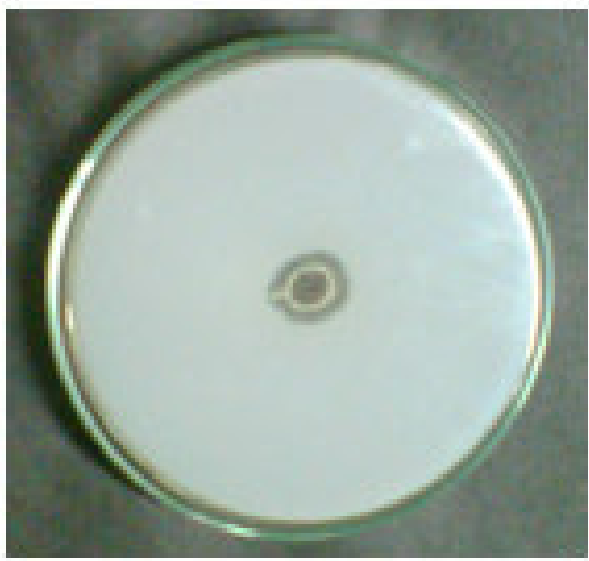

L PH 90

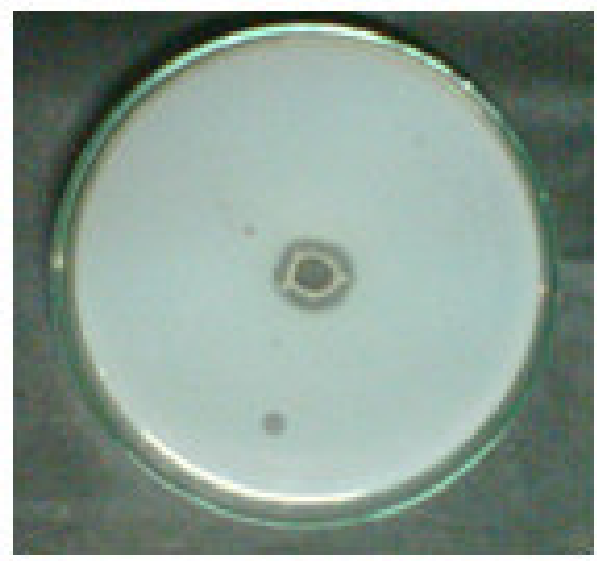

L $\mathrm{PH} 6.5$

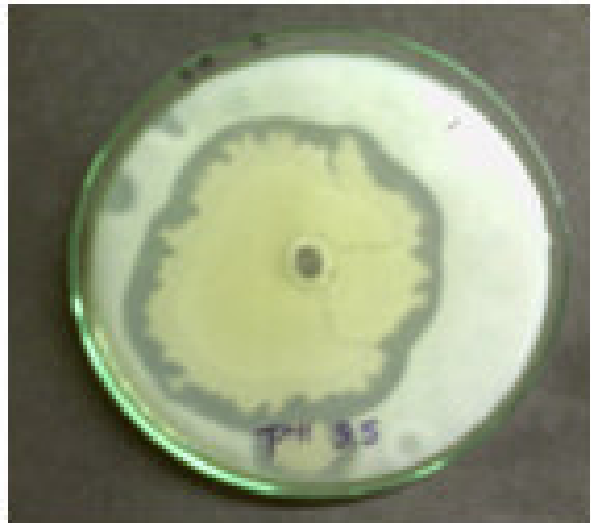

TPH 5.5

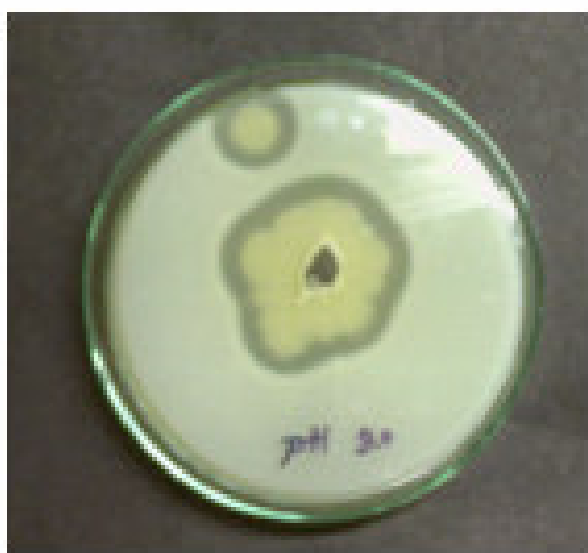

TPH 9.0

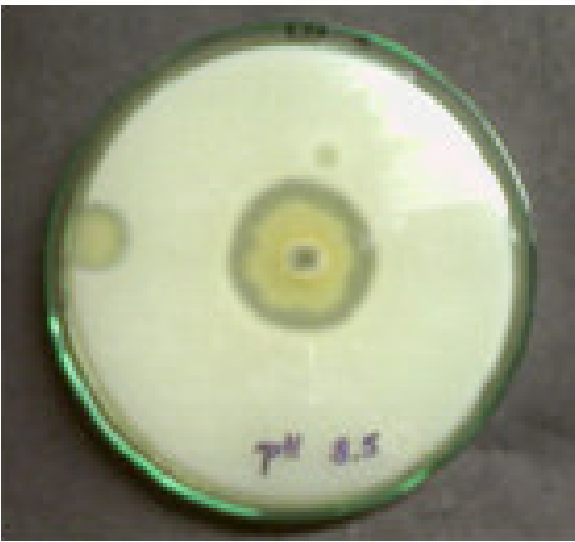

F $\mathrm{PH} 6.5$

Fig. 3- SMA plates with cold centrifuge $(\mathbf{\Lambda})$ and normal centrifuge $(\boldsymbol{\nabla})$ showing zone of clearance at $\mathrm{pH} 9.5$, 9 and 8.5.

Estimation of total extracellular soluble protein: The Bradford assay was performed in order to determine the total extracellular soluble protein content produced after 24 hours of fermentation. 


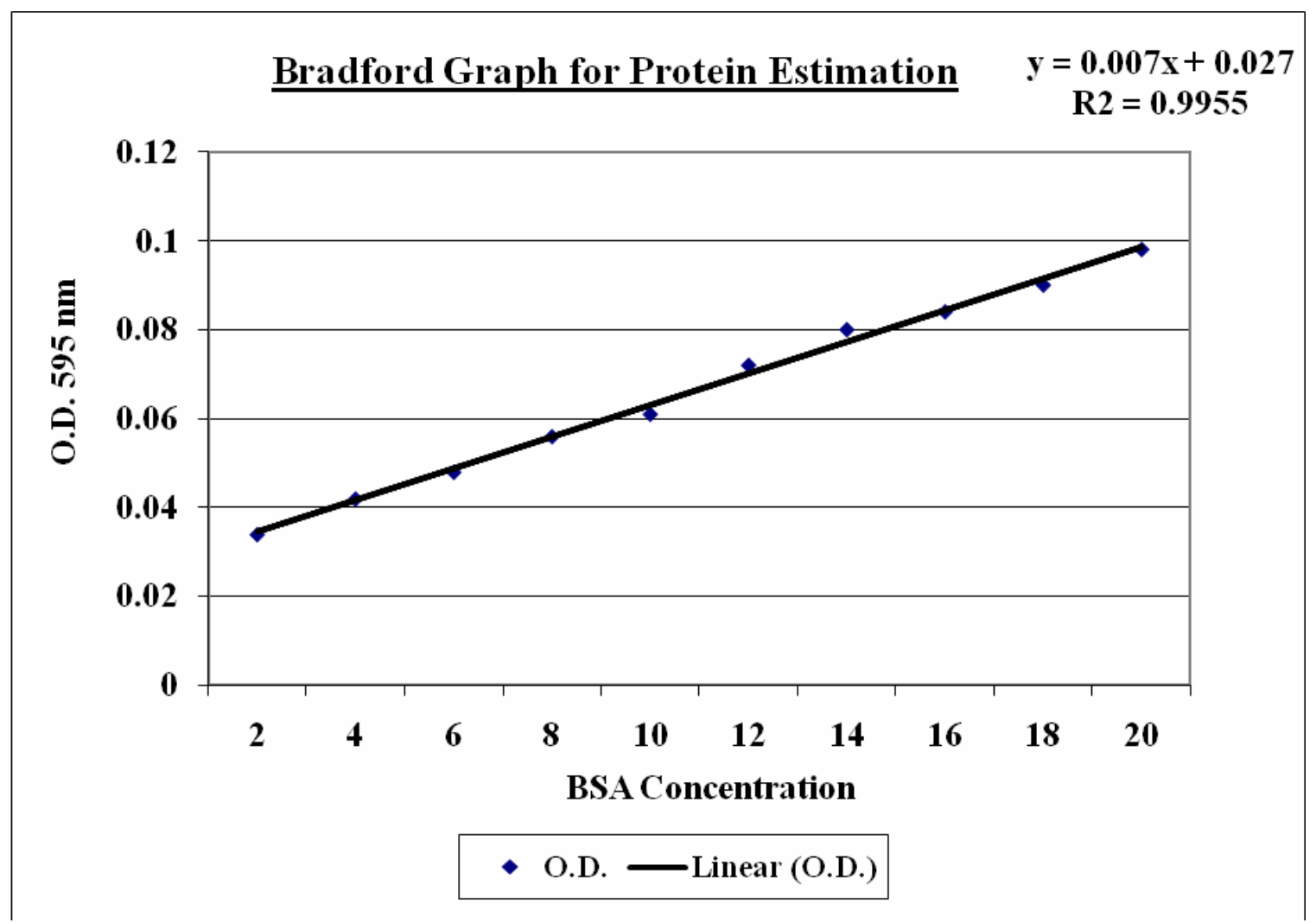

Fig. 4- Standard graph for Bradford

Similar procedure was followed for $\mathrm{pH}$ samples and following readings were obtained.

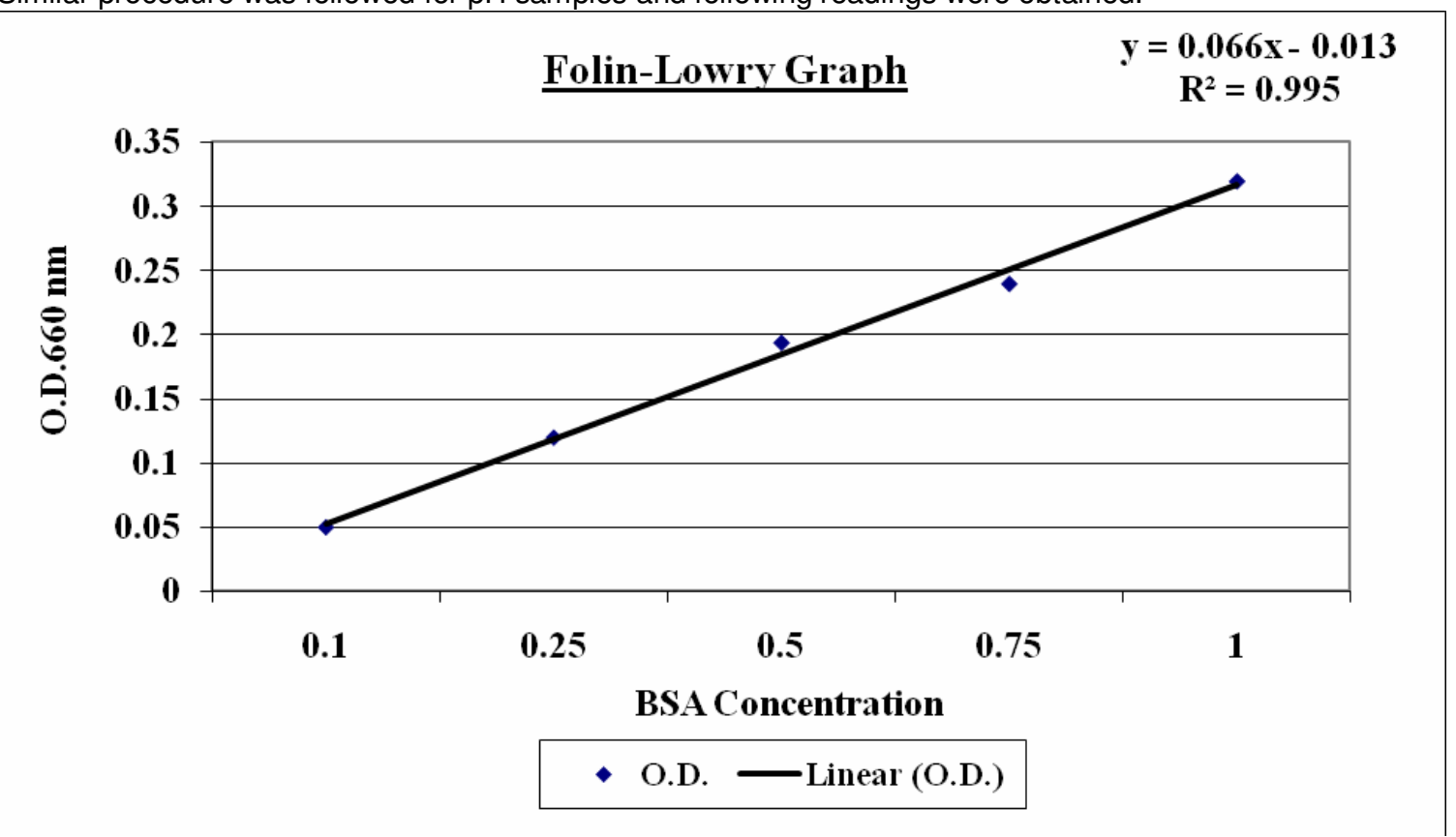

Fig. 5- Standard graph for Folin-Lowry 


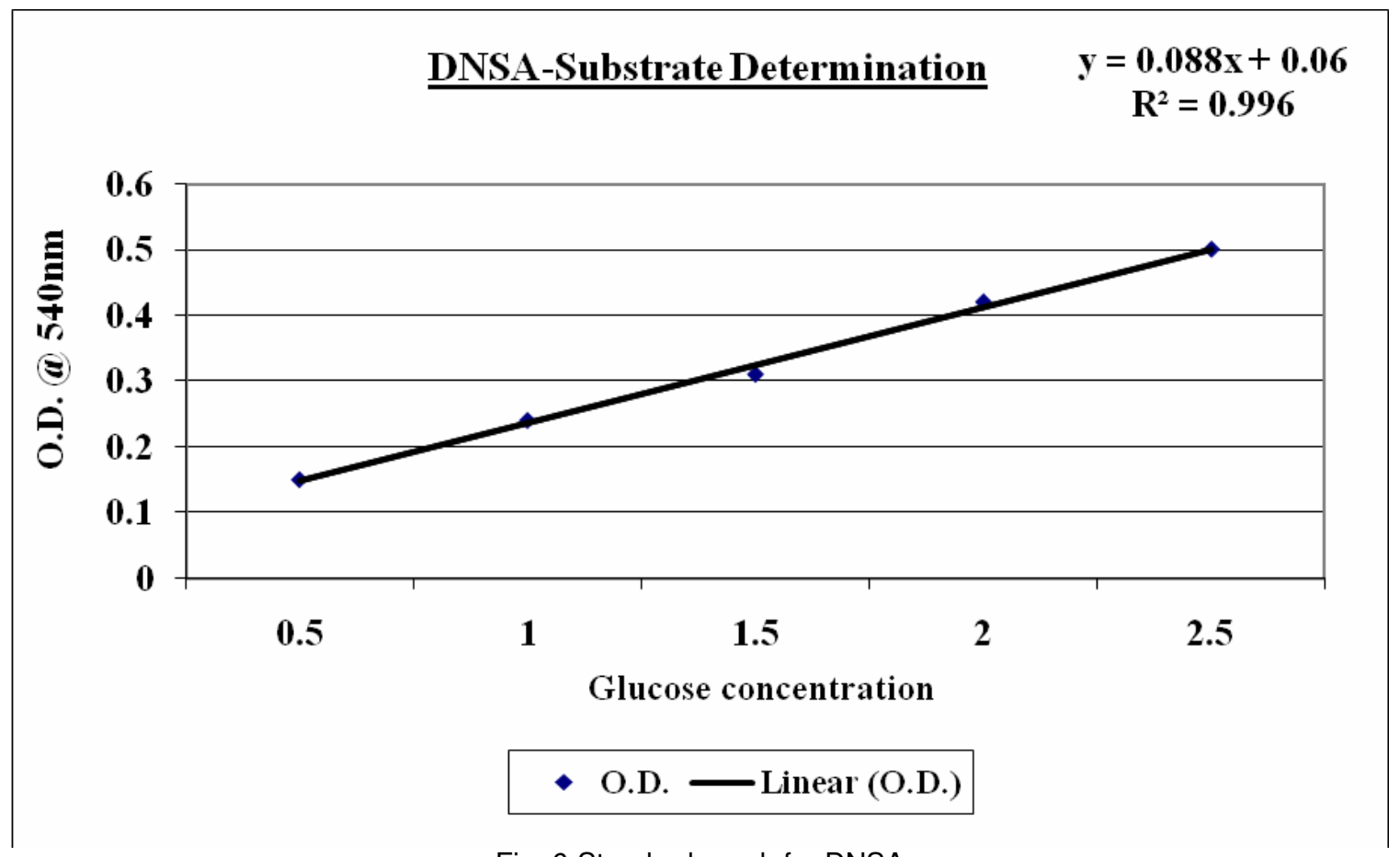

Fig. 6-Standard graph for DNSA

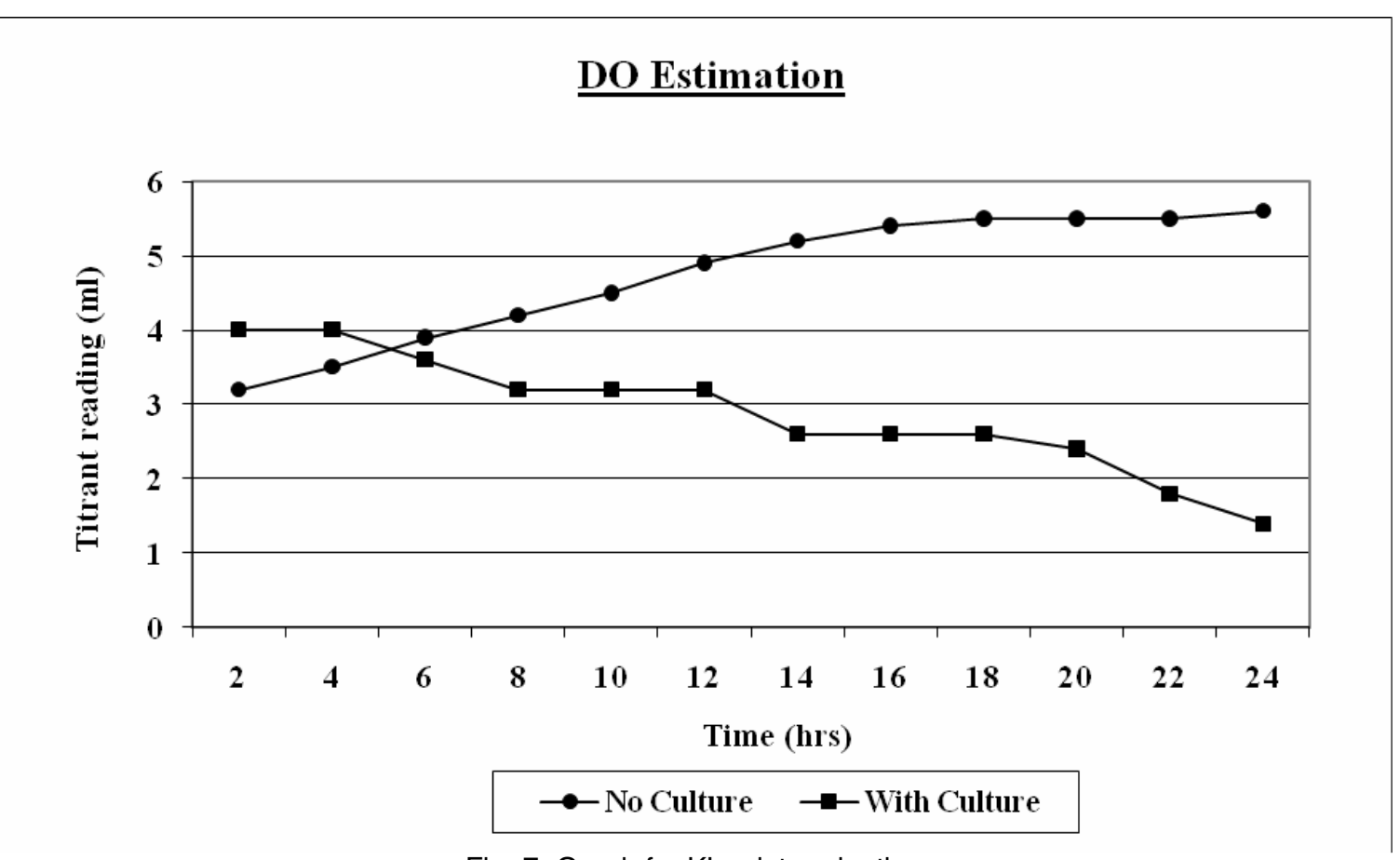

Fig. 7- Graph for KLa determination 


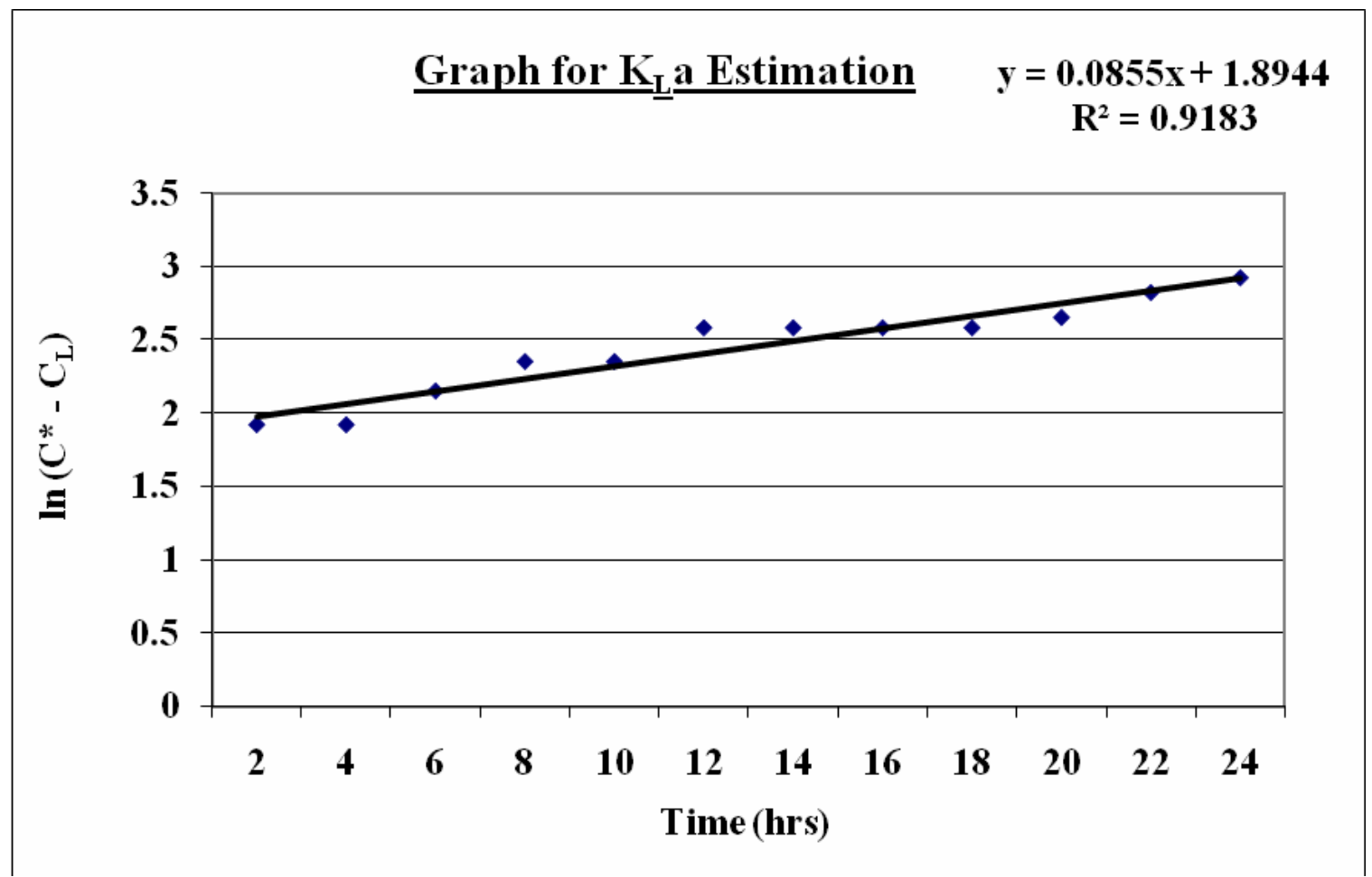

Fig. 8- KLa value of the bioreactor in the current study was calculated to be 0.0855 from the the slope of the above graph.

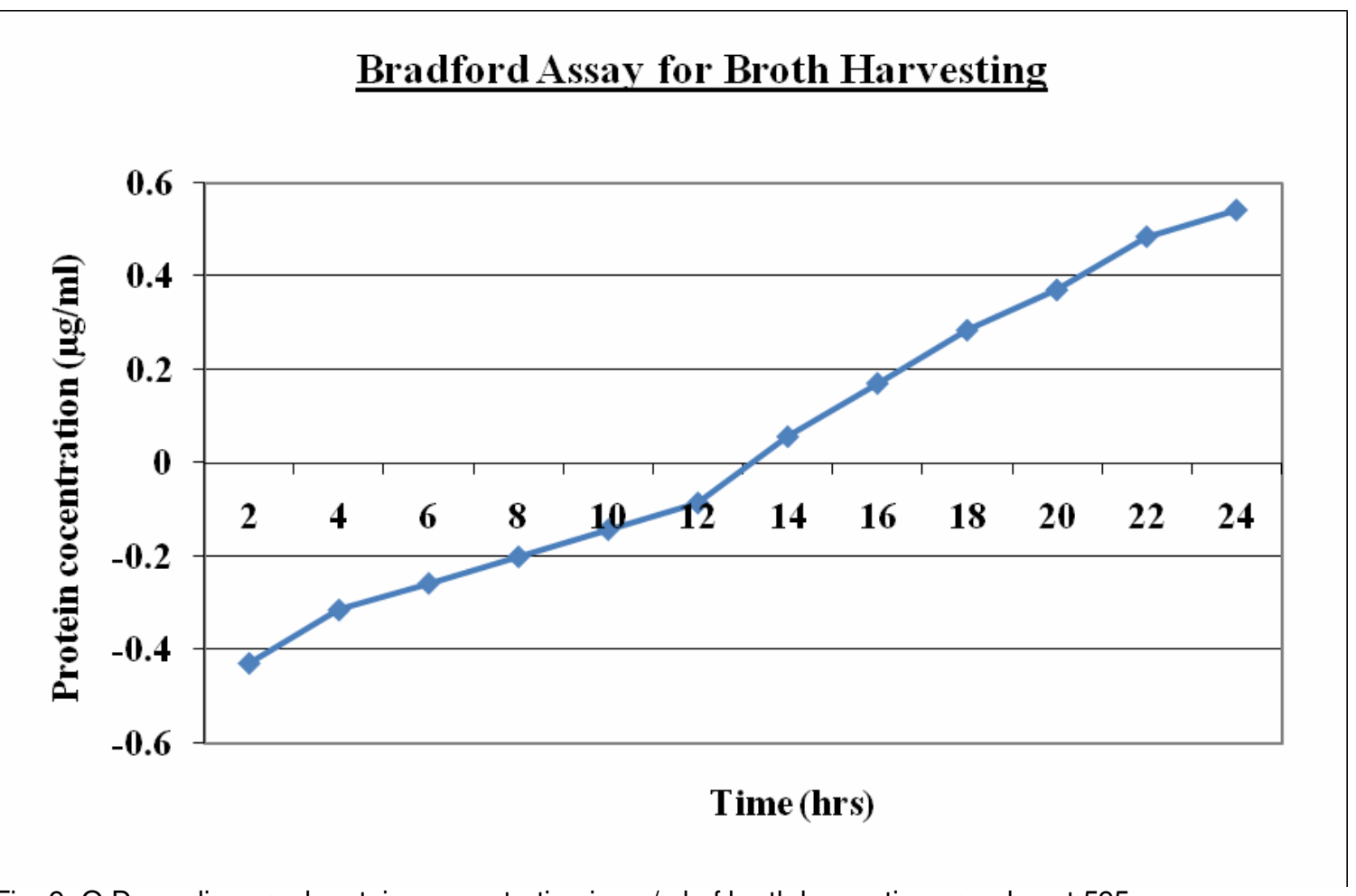

Fig. 9- O.D. readings and protein concentration in $\mu \mathrm{g} / \mathrm{ml}$ of broth harvesting samples at $595 \mathrm{~nm}$ 